\title{
Selectivity in the Pentacarbonyliron-Promoted Cyclocarbonylation of Enediynes
}

\author{
Anthony J. Pearson* and Alvise Perosa \\ Department of Chemistry, Case Western Reserve University, Cleveland, Ohio 44106
}

Received June 19, $1995^{\circledR}$

\begin{abstract}
Cyclocarbonylation reactions of a series of enediynes, promoted by pentacarbonyliron, proceed selectively on the diyne, resulting in the formation of cyclopentadienone-iron tricarbonyl complexes, without competing enyne cyclocarbonylation.
\end{abstract}

\section{Introduction}

Previous papers from our laboratory have described the preparation and intramolecular cyclocarbonylation reactions of a number of different enynes and $\alpha, \omega$-diynes to give the corresponding cyclopentenones (PausonKhand type reaction) or the corresponding cyclopentadienone- $\mathrm{Fe}(\mathrm{CO})_{3}$ complexes, exemplified by eqs 1 and $2 .{ }^{1-4}$

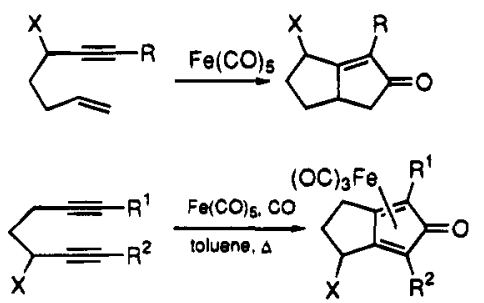

It was found that these reactions tolerate the presence of different functionalities. Hydroxy-substituted, electrondeficient acetylenes, as well as sterically crowded ones, undergo high-yielding intramolecular cyclocarbonylations. It was also shown that the hydroxy-substituted cyclopentadienone complexes can be oxidized to the corresponding ketones and that the products can be subjected to stereoselective nucleophilic addition. Demetalation was accomplished in some cases using trimethylamine $N$-oxide, and evidence of an unexpected mechanism for this reaction mechanism was obtained. ${ }^{1}$

Further studies of this cyclocarbonylation reaction were needed if it is to be employed in organic synthesis. The construction of the bicyclo[3.3.0]octadienone skeleton is of interest for the synthesis of a number of natural polyquinanes, some of which have already been approached by similar and by more traditional chemistry, such as coriolin, ${ }^{5,6}$ pentalenene, ${ }^{7-9}$ pentalenic acid, ${ }^{7,10}$ crinipellin, ${ }^{11}$ silphinene, ${ }^{7,12}$ hirsutene, ${ }^{13}$ and hirsutic acid. ${ }^{6}$

\footnotetext{
${ }^{\otimes}$ Abstract published in Advance ACS Abstracts, October 15, 1995.

(1) Pearson, A. J.; Shively, R. J., Jr. Organometallics 1994, 13, 578

(2) Pearson, A. J.; Shively, R. J., Jr.; Dubbert, R. A. Organometallics 1992, 11, 4096 .

(3) Pearson, A. J.; Dubbert, R. A. J. Chem. Soc., Chem. Commun. 1991, 91, 202.

(4) Pearson, A. J.; Dubbert, R. A. Organometallics 1994, 13, 1656.

(5) Magnus, P.; Exon, C. J. Am. Chem. Soc. 1983, 105, 2477

(6) Magnus, P.; Exon, C.; Albaugh-Robertson, G. J. Tetrahedron $1985,41,5861$

(7) Schore, N. E.; Rowley, E. G. J. Org. Chem. 1992, 57, 6853.

(8) Yamamura, S.; Shizuri, Y.; Maki, S.; Ohkubo, M. Tetrahedron Lett. 1990, 31, 7167.

(9) Burnell, D. J.; Zhu, Y.-Y.; Wu, Y.-J. J. Org. Chem. 1994, 59, 104. C5.

(10) Schore, N. E.; Rowley, E. G. J. Organomet. Chem. 1991, 413,

(11) Curran, D. P.; Schwartz, C. E. J. Am. Chem. Soc. 1990, 112, 9272
}

In the present work our first objective was to study the selectivity of these cyclocarbonylation reactions for substrates containing both acetylenic and olefinic functionalities. We will show how, under our conditions, the iron-promoted cyclocarbonylation reaction of enediynes occurs specifically on the diyne moiety.

Next, demetalation of the cyclopentadienone- $\mathrm{Fe}(\mathrm{CO})_{3}$ complexes had to be accomplished efficiently in order for the global scheme to be synthetically useful. Recently similar demetalation reactions have been reported from our laboratory ${ }^{1}$ and from Knölker and coworkers, ${ }^{14,15}$ by the use of $\mathrm{Me}_{3} \mathrm{NO}$. We will describe the problems encountered and the applicability of such demetalation procedures to our cases.

\section{Results and Discussion}

A series of enediynes was prepared starting from 4-pentyn-1-ol (Scheme 1). In the presence of 2 equiv of lithium amide in liquid ammonia at $-40{ }^{\circ} \mathrm{C}, 4$-pentyn1-ol reacted regiospecifically with 5-bromo-1-pentene to give the kinetically preferred substitution product $1 .^{16}$ The resulting alcohol 1 was converted, via the methanesulfonate 2 , to the corresponding iodide 3 , which acts as a better leaving group in the subsequent acetylide addition. ${ }^{17}$ It was then added to the appropriate acetylide to afford the desired enediynes 4 and 5 . Desilylation of 5 with TBAF gave 6 (eq 3 ).

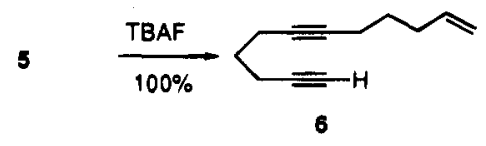

Alcohol 1 was oxidized using the Swern ${ }^{18}$ procedure to give the aldehyde 7 , which was then treated with the appropriate acetylide to give the desired enediyne alcohols 8 and 9 in good yields. This sequence can be easily performed on multigram scale, and rigorous purification of the intermediates is unnecessary.

Cyclocarbonylation of the enediynes was then investigated. An interesting feature of this reaction is its

(12) Franck-Neumann, M.; Miesch, M.; Gross, L. Tetrahedron Lett. $1991,32,2135$

(13) Castro, J.; Sorensen, H.; Riera, A.; Morin, C.; Moyano, A.; Pericas, M. A.; Greene, A. E. J. Am. Chem. Soc. 1990, 112, 9388.

(14) Knölker, H.-J.; Heber, J.; Mahler, C. H. Synlett 1992, 1002.

(15) Knölker, H.-J.; Heber, J. Synlett 1993, $12,924$.

(16) Brandsma, L. Preparative Acetylenic Chemistry, 2nd ed.; Elsevier: Amsterdam, 1988; Vol, 34.

(17) Ho, T. L. Chem. Rev. 1975, 75, 1

(18) Swern, D.; Huang, S.-L.; Mancuso, A. J. J. Org. Chem. 1978, 43,2480 .

(C) 1995 American Chemical Society 


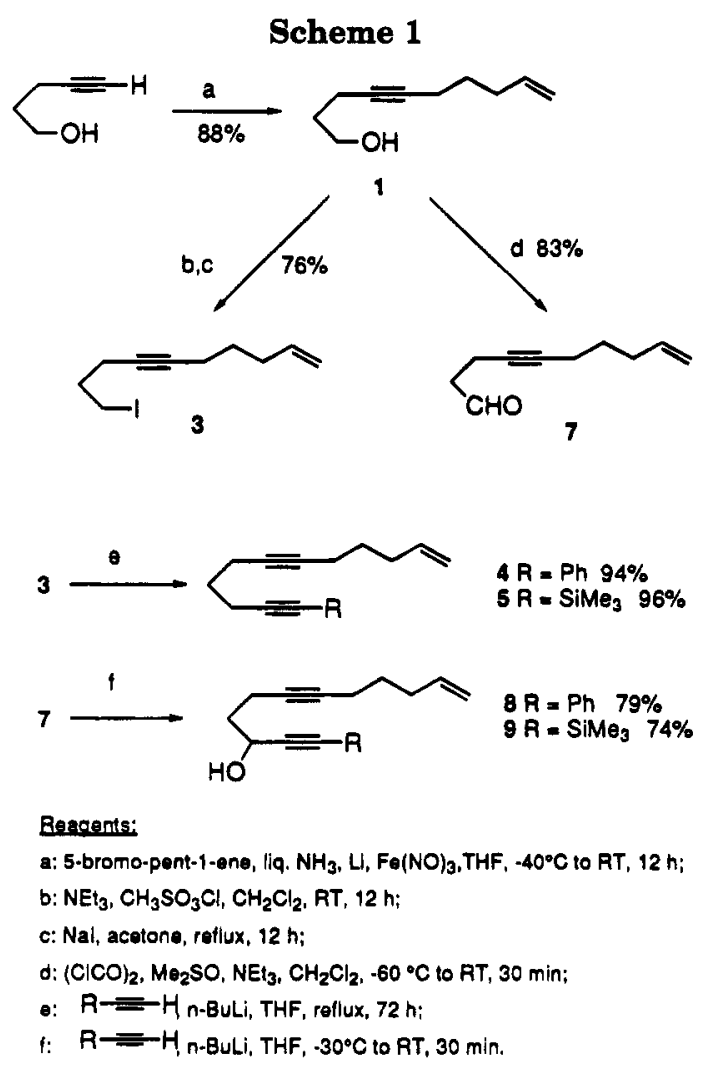

Scheme 2

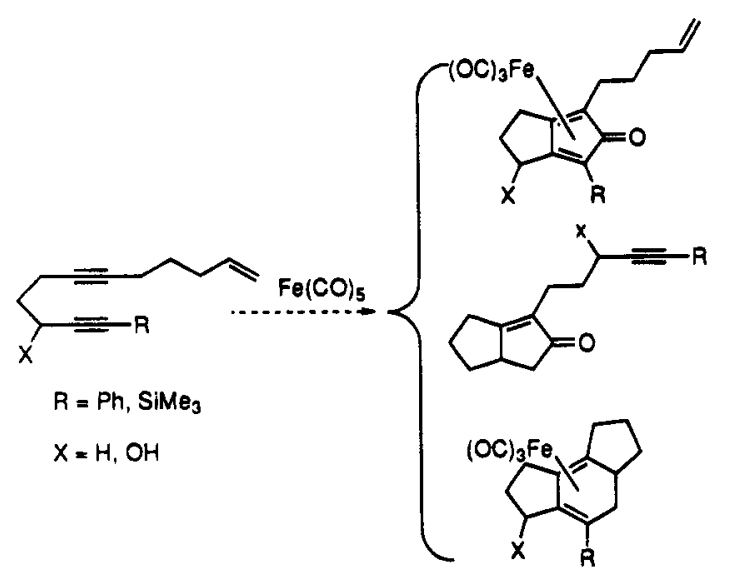

possible chemoselectivity deriving from the presence of the diyne and enyne moieties. Iron pentacarbonyl has been shown to promote cyclocarbonylation of 1,6-enynes to the corresponding bicyclo[3.3.0]pentenones (eq 1), 4 and diynes react with iron pentacarbonyl under $\mathrm{CO}$ pressure to generate the tricarbonylironbicyclo[3.3.0]dienones: ${ }^{1-3}$ a competing effect was thus possible, although we have observed that the enyne cyclocarbonylation is generally much slower than the diyne reaction. Vollhardt and co-workers have shown that acetylenic and olefinic functionalities present in the same molecule can participate in a cobalt-mediated annulation reaction to give a tricyclic complex (eq 4)..$^{19}$ Thus, a mixture of products arising from multiple concurrent reaction pathways might have been expected (Scheme 2).

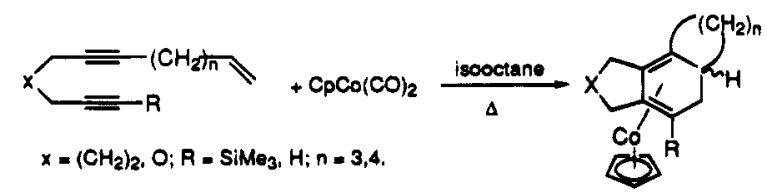

Very rewardingly it was found that the above enediynes, when subjected to the cyclocarbonylation conditions that have been previously described, ${ }^{1-3}$ react cleanly to give solely the complexes arising from diyne cyclocarbonylation, as summarized in eqs 5 and 6 .

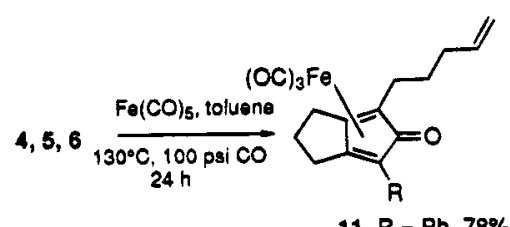

$11 R=\mathrm{Ph}, 78 \%$

$12 \mathrm{R}=\mathrm{SiMe}_{3}, 40 \%$

$13 R=H, 90 \%$

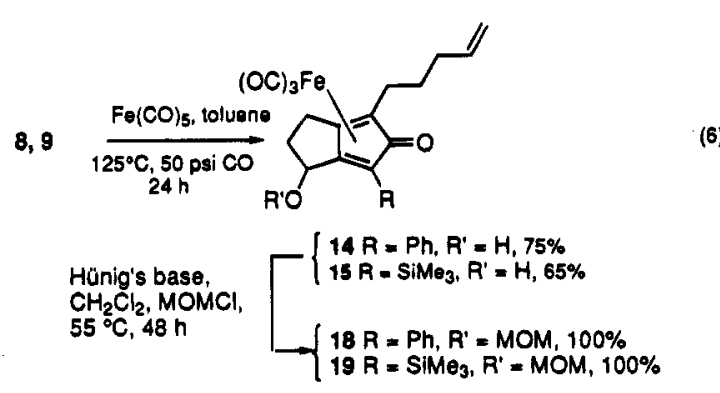

Proton NMR spectra of the crude products from all the above reactions showed no evidence of any cyclopentenones arising from participation of the olefin in the reaction. In the cases of eq 6 a roughly equimolar mixture of the syn and anti diastereomers was obtained, which were usually not separated in view of the subsequent demetalation reaction which destroys the chirality of the organometallic.

At this point it seemed interesting to develop a general and efficient demetalation procedure for our complexes, which would hopefully lead to the corresponding bicyclo[3.3.0]octadienones. In our case an added curiosity derives from the possibility that the free olefin side chain might react in an intramolecular Diels-Alder fashion with the highly reactive cyclopentadienone upon decomplexation. The demetalation reactions of complexes 11, 12, and 14-16 proved quite difficult to accomplish (eq 7). Initial attempts using the

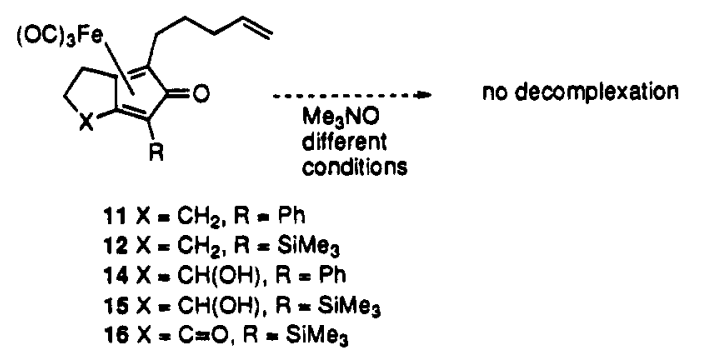

(7)

known procedures with $\mathrm{Me}_{3} \mathrm{NO}^{4,15,20,21}$ in acetone or benzene as solvents at various temperatures, and using ceric ammonium nitrate, ${ }^{22}$ proved unsuccessful. It was thought that decreasing the electron density on the complexed cyclopentadienone ring might help in the demetalation. The hydroxy-substituted complex was

(19) Vollhardt, K. P. C.; Sternberg, E. D. J. Am. Chem. Soc. 1980 102,4839

(20) Shvo, Y.; Hazum, E. J. Chem. Soc., Chem. Commun. 1974, 74, 336.

(21) Hogeveen, H.; Eekhof, J. H.; Kellog, R. M. J. Chem. Soc., Chem. Commun. 1976, $76,657$.

(22) Vollhardt, K. P. C.; Gesing, E. R. F.; Tane, J. P. Synlett 1980, 1002 . 
oxidized to the corresponding ketone 16 by standard treatment with PCC, but attempts to decomplex this compound by the usual methods also failed.

The importance of solvent is illustrated by the use of $\mathrm{Me}_{3} \mathrm{NO}$ in $N, N$-dimethylacetamide (DMA), which led to successful demetalation at $-5{ }^{\circ} \mathrm{C} .{ }^{23}$ The results are shown in eqs 8 and 9. As can be seen in each case, a

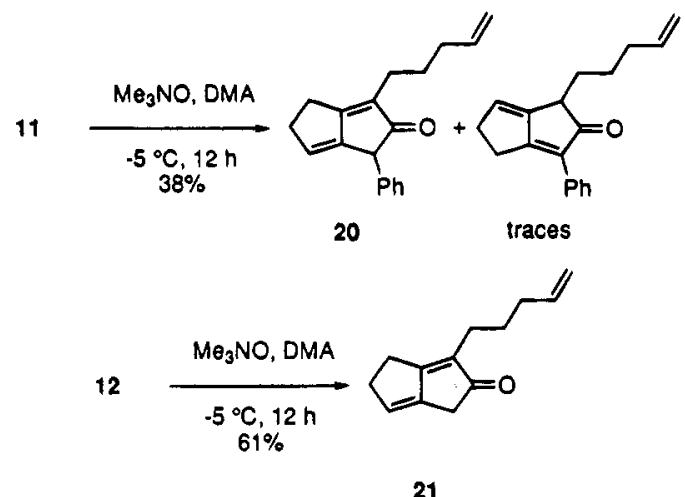

migration of one double bond occurs during this reaction, as has been observed previously by Knölker and co-workers. ${ }^{15}$ We believe this is due to the increased basicity of $\mathrm{Me}_{3} \mathrm{NO}$ in DMA that allows for an easy deprotonation at the $\gamma$-carbon followed by reprotonation at the $\alpha$-position, followed by desilylation. The trimethylsilyl group plays a very important role in controlling the site of deprotonation and accompanying deconjugation.

Surprisingly, decomplexation of the hydroxy complexes 14 and 15 did not occur under the preceding conditions. There appears to be some oxidation occurring at the hydroxyl oxygen, but the products were extremely unstable and were uncharacterizable. To overcome this, the hydroxy complex 15 was protected as the trimethylsilyl ether 17. Although some TLC evidence of the demetalated product was obtained, it was not possible to isolate and characterize it. A second attempt was made by protecting 14 and 15 as their MOM ethers: 18 and 19. Upon subjecting these compounds to our demetalation conditions, we were able to isolate the bicyclooctadienones 22 and 23 in moderate to good yields (eqs 10 and 11).

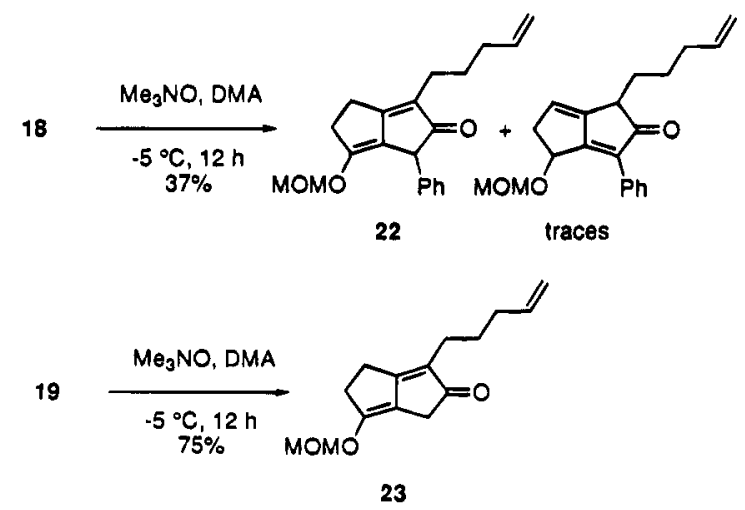

As in the preceding cases migration of a double bond and desilylation were observed. It should be noted that compounds 22 and $\mathbf{2 3}$ are each the protected and

(23) Bandara, B. M. R.; Birch, A. J.; Kelly, L. F. J. Org. Chem. 1984, 49,2496 . masked enol form of an enedione, which can can be considered as the products of a Pauson-Khand type reaction of an electron-deficient $\alpha, \beta$-unsaturated enyne such as that shown in eq 12. This is noteworthy since

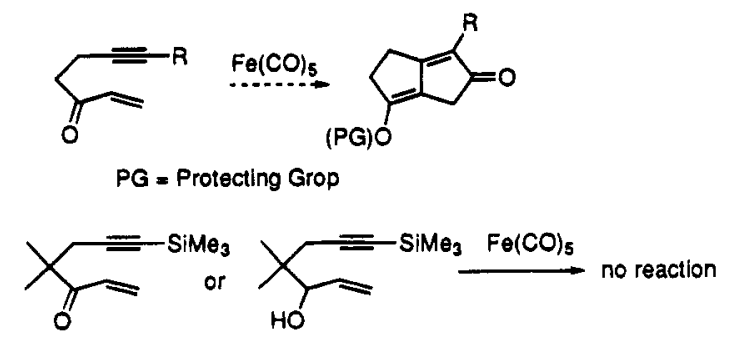

electron-deficient alkenes are usually poor substrates for Pauson-Khand reactions, ${ }^{24,25}$ there being only a few examples in the literature. ${ }^{26-28}$ The pentacarbonyliron promoted Pauson-Khand type reaction on such electrondeficient alkenes also does not occur in the presence of pentacarbonyliron; unpublished attempts from our group to achieve the reaction shown in eq 13 proved unsuccessful. The scope of our pentacarbonyliron promoted cyclocarbonylation is thus extended to formally include intramolecular Pauson-Khand type cyclizations of electron deficient $\alpha, \beta$-unsaturated enynes.

\section{Experimental Section}

General Methods. The syntheses were carried out under a purified nitrogen atmosphere. $\mathrm{THF}$ and $\mathrm{Et}_{2} \mathrm{O}$ were distilled from $\mathrm{Na}$ /benzophenone, $\mathrm{CH}_{2} \mathrm{Cl}_{2}$ from $\mathrm{CaH}_{2}$, and acetone from $\mathrm{CaSO}_{4}$. All other solvents were used as purchased. All nonvolatile compounds were dried of residual solvents by exposure to high vacuum prior to analysis.

Infrared spectra were recorded on a Nicolet Impact FT-IR spectrometer in $\mathrm{NaCl}$ chambers. ${ }^{1} \mathrm{H}\left({ }^{13} \mathrm{C}\right) \mathrm{NMR}$ spectra were recorded at 300 (75) $\mathrm{MHz}$ on a Varian Gemini spectrometer, unless otherwise noted, and were referenced to the solvent or to TMS. NMR assignments for some complexes were made on separated pure diastereomers; in several other cases the assignments were made on the mixtures of diastereomers by comparison with the purified materials. Mass spectra were recorded on a Kratos MS25A instrument.

Gas chromatography was performed on an Hewlett Packard 5890 Series II instrument fitted with a HP-5 $30 \mathrm{~m} \times 0.32 \mathrm{~mm}$ capillary column coated with a $0.25 \mathrm{~mm}$ film of $5 \% \mathrm{PhMe}$ Silicone, equipped with a flame ionization detector, using $\mathrm{He}$ as carrier gas. The temperature gradient program, in each case the same, was the following: start at $120^{\circ} \mathrm{C}$, increase to 150 ${ }^{\circ} \mathrm{C}$ at $5^{\circ} \mathrm{C} / \mathrm{min}$, and then to $250^{\circ} \mathrm{C}$ at $10^{\circ} \mathrm{C} / \mathrm{min}$, for $2 \mathrm{~min}$.

Deca-9-en-4-yne-1-ol (1). To $300 \mathrm{~mL}$ of liquid ammonia at $-78^{\circ} \mathrm{C}$ is added enough lithium metal $(\sim 30 \mathrm{mg}, \sim 4.3 \mathrm{mmol})$ to turn the solution deep blue. After addition of a catalytic amount of ferric nitrate nonahydrate $(5 \mathrm{mg}, 0.02 \mathrm{mmol}$ ) the solution turns brownish, at which point the remaining lithium is added ( $200 \mathrm{mg}, 28.8 \mathrm{mmol}$ ). The solution turns blue again, and as it is warmed to $-40^{\circ} \mathrm{C}$, it becomes a whitish suspension $\left(\mathrm{LiNH}_{2}\right)$. 4-Pentyn-1-ol $(840 \mathrm{mg}, 10 \mathrm{mmol})$ is added to the suspension at $-40^{\circ} \mathrm{C}$ over $20 \mathrm{~min}$, followed by $1.49 \mathrm{~g}(10 \mathrm{mmol})$ of 5-bromopent-1-ene over $30 \mathrm{~min}$. The solution is stirred at the boiling point of ammonia $\left(-33^{\circ} \mathrm{C}\right)$ for $3 \mathrm{~h}$ after which 50 $\mathrm{mL}$ of THF is added; the ammonia is then left to evaporate overnight. The resulting THF solution is quenched with 100

(24) Pauson, P. L.; Khand, I. U. J. Chem. Soc. Chem., Commun 1974, 379 .

25) Schore, N. E. Org. React. 1991, 40, 1.

(26) Veretenov, A. L.; Smit, W. A.; Vorontsova, L. G.; Kurella, M. G.; Caple, R.; Gybin, A. S. Tetrahedron Lett. 1991, 32, 2109.

(27) Costa, M.; Mor, A. Tetrahedron Lett. 1995, 36, 2867.

(28) Krafft, M. E.; Wright, C. Tetrahedron Lett. 1992, 33, 151. 
$\mathrm{mL}$ of cold water, the aqueous layer is extracted three times with ethyl ether, and the combined organic layers are washed twice with brine. After drying over $\mathrm{MgSO}_{4}$ and removal of the solvent, the product is purified by flash chromatography ( $R_{f}=0.40$ in $10 \%$ EtOAc/hexanes) and obtained as a yellow oil in $88 \%$ yield: $\mathrm{GC} \mathrm{Rt}=5.3 \mathrm{~min}$; IR $\left(\mathrm{CCl}_{4}\right) 3641,3323,3079$, $2937 \mathrm{~cm}^{-1} ;{ }^{1} \mathrm{H}$ NMR $\left(\mathrm{CDCl}_{3}\right) \delta 5.84-5.60(\mathrm{~m}, 1 \mathrm{H}), 5.02-4.92$ $(\mathrm{m}, 2 \mathrm{H}), 3.73(\mathrm{t}, 2 \mathrm{H}, J=6.1 \mathrm{~Hz}), 2.25(\mathrm{td}, 2 \mathrm{H}, J=4.3,2.4$ $\mathrm{Hz}), 2.12(\mathrm{~m}, 4 \mathrm{H}), 1.80-1.66(\mathrm{~m}, 3 \mathrm{H}), 1.55(\mathrm{p}, 2 \mathrm{H}, J=7.29$ $\mathrm{Hz}) ;{ }^{13} \mathrm{C} \mathrm{NMR}\left(\mathrm{CDCl}_{3}\right) \delta 138,115,81,80,62,33,32,28,18$, 15. HRMS: calcd for $\mathrm{C}_{10} \mathrm{H}_{16} \mathrm{O}\left(\mathrm{M}^{+}\right)$, m/e 152.1201; found, $m / e$ 152.1191 .

1-((Methylsulfonyl)oxy)deca-9-en-4-yne (2). To 1 (0.507 $\mathrm{g}, 3.3 \mathrm{mmol}$ ) in $25 \mathrm{~mL}$ of $\mathrm{CH}_{2} \mathrm{Cl}_{2}$ are added $1 \mathrm{~mL}$ of $\mathrm{Et}_{3} \mathrm{~N}$ and, at $-30{ }^{\circ} \mathrm{C}, 0.25 \mathrm{~mL}(3.3 \mathrm{mmol})$ of methanesulfonyl chloride. The solution is stirred at room temperature overnight. The solvent is removed, and the solid mass is diluted with $30 \mathrm{~mL}$ of ethyl ether. Workup with $10 \% \mathrm{NaHCO}_{3}$ and brine, followed by drying over magnesium sulfate and removal of the solvent, affords the product as a yellow oil $\left(R_{f}=0.74\right.$ in $10 \% \mathrm{EtOAc}$ hexanes), in $86 \%$ yield: GC Rt $=12.1 \mathrm{~min}$; IR $\left(\mathrm{CCl}_{4}\right) 3161$, $3085,2945,2262,1807,1645 \mathrm{~cm}^{-1} ;{ }^{1} \mathrm{H}$ NMR $\left(\mathrm{CDCl}_{3}\right) \delta 5.80-$ $5.72(\mathrm{~m}, 1 \mathrm{H}), 5.03-4.93(\mathrm{~m}, 2 \mathrm{H}), 4.33(\mathrm{t}, 2 \mathrm{H}, J=6.1 \mathrm{~Hz}), 3.00$ $(\mathrm{s}, 3 \mathrm{H}), 2.32-2.27(\mathrm{~m}, 2 \mathrm{H}), 2.13(\mathrm{~m}, 4 \mathrm{H}), 1.93-1.84(\mathrm{~m}, 2 \mathrm{H})$, $1.54(\mathrm{p}, 2 \mathrm{H}) ;{ }^{13} \mathrm{C} \mathrm{NMR}\left(\mathrm{CDCl}_{3}\right) \delta 138,115 ., 81,77,69,37,33$, $28,28,18,15$. HRMS: calcd for $\mathrm{C}_{10} \mathrm{H}_{15} \mathrm{O}\left(\mathrm{M}^{+}-\mathrm{SO}_{2} \mathrm{CH}_{3}\right), m / e$ 151.1123; found, m/e 151.1123.

1-Iodo-deca-9-en-4-yne (3). A solution of 2 in $25 \mathrm{~mL}$ of acetone $(0.685 \mathrm{~g}, 2.85 \mathrm{mmol})$ was refluxed overnight with 0.500 $\mathrm{g}(3.2 \mathrm{mmol})$ of NaI. Removal of the acetone, dilution with ether, and aqueous workup, followed by drying over magnesium sulfate and removal of the solvent, affords the product as a yellow oil, which over times tends to darken ( $88 \%$ yield) $\left(R_{f}=0.61\right.$ in $10 \% \mathrm{EtOAc} /$ hexanes $):$ GC Rt $=8.1 \mathrm{~min}$; IR $\left(\mathrm{CCl}_{4}\right)$ $3315,3160,2951,2260 \mathrm{~cm}^{-1} ;{ }^{1} \mathrm{H}$ NMR $\left(\mathrm{CDCl}_{3}\right) \delta 5.82-5.72$ $(\mathrm{m}, 1 \mathrm{H}), 5.04-4.94(\mathrm{~m}, 2 \mathrm{H}), 3.28(\mathrm{t}, 2 \mathrm{H}, J=6.7 \mathrm{~Hz}), 2.30-$ $2.24(\mathrm{~m}, 2 \mathrm{H}), 2.13(\mathrm{~m}, 4 \mathrm{H}), 1.98-1.89(\mathrm{~m}, 2 \mathrm{H}), 1.55(\mathrm{p}, 2 \mathrm{H})$; ${ }^{13} \mathrm{C}$ NMR $\delta 138,115,81,78,33,32,28,20,18,6$. HRMS: calcd for $\mathrm{C}_{10} \mathrm{H}_{15} \mathrm{I}\left(\mathrm{M}^{+}\right)$, m/e 262.0219; found, m/e 262.0203.

12-Phenyldodeca-6,11-diyne-1-ene (4) and 12-(Trimethylsilyl)dodeca-6,11-diyne-1-ene (5). These products were prepared by following an identical procedure. The appropiate acetylene ( $3 \mathrm{mmol}$ ) dissolved in $10 \mathrm{~mL}$ of THF is treated at $-78^{\circ} \mathrm{C}$ with $3 \mathrm{mmol}$ of a $1.6 \mathrm{M}$ solution of $n-\mathrm{BuLi}$ in hexanes. The solution is warmed to $0^{\circ} \mathrm{C}$ to ensure complete deprotonation, $2 \mathrm{mmol}$ of 3 is added, and the solution is brought to reflux. Small aliquots $(1-2 \mathrm{mmol})$ of preformed acetylide are added via cannula until complete conversion of 10-iododec-6-yne-1-ene is observed by GC ( 1 to 2 days). The mixture is then worked up as usual and dried over $\mathrm{MgSO}_{4}$. Removal of the solvent affords a clear yellow oil which is purified by flash chromatography. 4: Yield $94 \% ; R_{f}=0.46$ (10\% EtOAc in hexanes); IR $\left(\mathrm{CHCl}_{3}\right) 2940,2250 \mathrm{~cm}^{-1} ;{ }^{1} \mathrm{H}$ NMR $\left(\mathrm{CDCl}_{3}\right) \delta 7.38-7.35(\mathrm{~m}, 2 \mathrm{H}), 7.27-7.22(\mathrm{~m}, 3 \mathrm{H}), 5.82-5.73$ $(\mathrm{m}, 1 \mathrm{H}), 2.50(\mathrm{t}, 2 \mathrm{H}), 2.31(\mathrm{~m}, 2 \mathrm{H}), 2.14(\mathrm{~m}, 4 \mathrm{H}), 1.76(\mathrm{p}, 2 \mathrm{H})$, $1.56(\mathrm{p}, 2 \mathrm{H}) ;{ }^{13} \mathrm{C} \mathrm{NMR}\left(\mathrm{CDCl}_{3}\right) \delta 138,132,128,128,124,115$, 89, 81, 80,79,33, 28, 28, 19, 18, 18. HRMS: calcd for $\mathrm{C}_{18} \mathrm{H}_{20}$ $\left(\mathrm{M}^{+}\right), m / e$ 236.1565; found, $m / e$ 236.1567. 5: Yield 96\%; $R_{f}=$ 0.75 (10\% EtOAc in hexanes); GC Rt $=10.7 \mathrm{~min}$; IR 2945 , $1649,1248 \mathrm{~cm}^{-1} ;{ }^{1} \mathrm{H}$ NMR $\left(\mathrm{CDCl}_{3}\right) \delta 5.82-5.73(\mathrm{~m}, 1 \mathrm{H}), 5.04-$ $4.93(\mathrm{~m}, 2 \mathrm{H}), 2.31(\mathrm{t}, 2 \mathrm{H}, J=7.14 \mathrm{~Hz}), 2.23(\mathrm{~m}, 2 \mathrm{H}), 2.14(\mathrm{~m}$, $4 \mathrm{H}), 1.67(\mathrm{p}, 2 \mathrm{H}, J=7.07 \mathrm{~Hz}), 1.55(\mathrm{p}, 2 \mathrm{H}, J=7.28 \mathrm{~Hz}), 0.12$ (s, 9H); ${ }^{13} \mathrm{C} \mathrm{NMR}\left(\mathrm{CDCl}_{3}\right) \delta 138,115,107,85,80,79,33,28$, 19, 18, 0. HRMS: calcd for $\mathrm{C}_{14} \mathrm{H}_{21} \mathrm{Si}\left(\mathrm{M}^{+}-\mathrm{CH}_{3}\right)$, m/e 217.1412; found $m / e$ 217.1412.

Dodeca-6,11-diyne-1-ene (6). To 5 dissolved in THF is added 1.5 equiv of tetrabutylammonium fluoride $(1.0 \mathrm{M}$ in $\mathrm{THF}$ ) at RT (room temperature) for $20 \mathrm{~min}$. Usual workup affords a quantitative yield of the product $\left(R_{f}=0.56\right.$ in $10 \%$ EtOAc/hexanes): IR $\left(\mathrm{CCl}_{4}\right) 3308,2934,1552 \mathrm{~cm}^{-1} ;{ }^{1} \mathrm{H}$ NMR $\left(\mathrm{CDCl}_{3}\right) \delta 5.73-5.62(\mathrm{~m}, 1 \mathrm{H}), 5.04-4.85(\mathrm{~m}, 2 \mathrm{H}), 2.21(\mathrm{qd}, 2 \mathrm{H}$, $\left.J_{1}=7.8 \mathrm{~Hz}, J_{2}=2.9 \mathrm{~Hz}\right), 2.09(\mathrm{~m}, 4 \mathrm{H}), 1.88(7,1 \mathrm{H}, J=2.9$
$\mathrm{Hz}), 1.64(\mathrm{p}, 2 \mathrm{H}, J=8.0 \mathrm{~Hz}), 1.51(\mathrm{p}, 2 \mathrm{H}, J=7.8 \mathrm{~Hz}) ;{ }^{13} \mathrm{C}$ NMR $\delta 138.0,115.0,83.8,80.6,79.1,68.6,32.8,28.2,28.0$, 18.1, 17.8, 17.5. HRMS: calcd for $\mathrm{C}_{12} \mathrm{H}_{16}\left(\mathrm{M}^{+}\right)$, m/e 160.1252; found, $m / e 160.1251$.

Deca-9-en-4-yn-1-al (7). Via the Swern procedure, to a solution of $\mathrm{CH}_{2} \mathrm{Cl}_{2}(25 \mathrm{~mL})$ and oxalyl chloride $(13.7 \mathrm{~mL}, 15.1$ $\mathrm{mmol}$ ) is added, at $-55{ }^{\circ} \mathrm{C}, \mathrm{Me}_{2} \mathrm{SO}(23.3 \mathrm{~mL}, 30.2 \mathrm{mmol})$ dissolved in $5 \mathrm{~mL}$ of $\mathrm{CH}_{2} \mathrm{Cl}_{2}$. After the mixture is stirred for

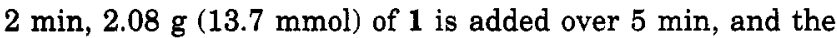
solution is stirred for an additional $15 \mathrm{~min}$, after which triethylamine $(9.6 \mathrm{~mL}, 68.5 \mathrm{mmol})$ is added. The reaction is then stirred below $-50^{\circ} \mathrm{C}$ for $5 \mathrm{~min}$ and then allowed to warm to room temperature. Water $(50 \mathrm{~mL})$ is added, and the aqueous layer is reextracted with additional $50 \mathrm{~mL}$ of $\mathrm{CH}_{2}$ $\mathrm{Cl}_{2}$. The combined organic layers are washed with saturated $\mathrm{NaCl}$ solution $(100 \mathrm{~mL})$, then with $1 \% \mathrm{HCl}$, water, and $5 \%$ $\mathrm{Na}_{2} \mathrm{CO}_{3}$, and finally with water. After drying over $\mathrm{MgSO}_{4}$ and removal of the solvent, the product is purified for analytical purposes by flash chromatography: $R_{f}=0.31$ in $10 \%$ EtOAc in hexanes; yield $1.70 \mathrm{~g}(11.3 \mathrm{mmol}), 83 \%$; GC Rt $=4.5 \mathrm{~min}$; IR $\left(\mathrm{CCl}_{4}\right) 1729,1546 \mathrm{~cm}^{-1} ;{ }^{1} \mathrm{H}$ NMR $\left(\mathrm{CDCl}_{3}\right) \delta 9.77(\mathrm{t}, J=1.4$ $\mathrm{Hz}$ ), 5.75 (ddt, $1 \mathrm{H}, J_{\text {trans }}=17.0 \mathrm{~Hz}, J_{\text {cis }}=10.3 \mathrm{~Hz}, J_{1}=6.6$ $\mathrm{Hz}), 4.99\left(\mathrm{dd}, 1 \mathrm{H}, J_{\text {trans }}=17.0 \mathrm{~Hz}, J_{\mathrm{gem}}=1.6 \mathrm{~Hz}\right), 4.94(\mathrm{dd}$, $\left.1 \mathrm{H}, J_{\text {cis }}=10.3 \mathrm{~Hz}, J_{\text {gem }}=1.6 \mathrm{~Hz}\right), 2.60\left(\mathrm{dt}, 2 \mathrm{H}, J_{1}=7.1 \mathrm{~Hz}, J_{2}\right.$ $=1.4 \mathrm{~Hz}), 2.46(\mathrm{~m}, 2 \mathrm{H}), 2.11(\mathrm{~m}, 4 \mathrm{H}), 1.53(\mathrm{p}, 2 \mathrm{H}) ;{ }^{13} \mathrm{C} \mathrm{NMR}$ $\left(\mathrm{CDCl}_{3}\right) \delta 201.0,137.9,115.0,81.1,78.1,43.0,32.7,28.0,18.0$, 12.1. HRMS: calcd for $\mathrm{C}_{10} \mathrm{H}_{14} \mathrm{O}\left(\mathrm{M}^{+}\right)$, m/e 150.1045; found, m/e 150.1041 .

3-Hydroxy-1-phenyldodeca-1,6-diyn-12-ene (8) and 3-Hydroxy-1-(trimethylsilyl)dodeca-1,6-diyn-12-ene (9). These products were prepared following an identical procedure. The appropriate acetylene $(3 \mathrm{mmol})$ dissolved in $10 \mathrm{~mL}$ of THF is treated at $-78^{\circ} \mathrm{C}$ with $3 \mathrm{mmol}$ of a $1.6 \mathrm{M}$ solution of $n-\mathrm{BuLi}$ in hexanes. The solution is warmed to $0^{\circ} \mathrm{C}$ to ensure complete deprotonation, it is cooled to between -50 and $-60{ }^{\circ} \mathrm{C}$, and dec-6-yne-10-ene-1-al (2.5 mmol) is added over 5-10 min. After the reaction mixture is allowed to warm to $0{ }^{\circ} \mathrm{C}$, it is poured into a mixture of ice and $10 \% \mathrm{NH}_{4} \mathrm{Cl}$, the aqueous layer is reextracted with ethyl ether, and the combined organic layers are dried over anhydrous $\mathrm{MgSO}_{4}$; after removal of the solvent the crude product is purified by flash chromatography. 8: Yield $=79 \% ; R_{f}=0.19$ (10\% EtOAc in hexanes); GC Rt $=16.6$ min; IR $\left(\mathrm{CCl}_{4}\right) 3679,3605,3035,2943,1224 \mathrm{~cm}^{-1} ;{ }^{1} \mathrm{H}$ NMR $\left(\mathrm{CDCl}_{3}\right) \delta 7.32(\mathrm{~m}, 2 \mathrm{H}), 7.21(\mathrm{~m}, 3 \mathrm{H}), 5.70\left(\mathrm{ddt}, 1 \mathrm{H}, J_{\text {trans }}=\right.$ $\left.17.0 \mathrm{~Hz}, J_{c i s}=10.3 \mathrm{~Hz}, J_{1}=6.6 \mathrm{~Hz}\right), 4.94\left(\mathrm{dd}, 1 \mathrm{H}, J_{\text {trans }}=\right.$ $\left.17.0 \mathrm{~Hz}, J_{\text {gem }}=1.6 \mathrm{~Hz}\right), 4.89\left(\mathrm{dd}, 1 \mathrm{H}, J_{\text {cis }}=10.3 \mathrm{~Hz}, J_{\text {gem }}=\right.$ $1.6 \mathrm{~Hz}), 4.66\left(\mathrm{dt}, 1 \mathrm{H}, J_{\mathrm{a}}=J_{\mathrm{b}}=6.0 \mathrm{~Hz}\right), 4.71(\mathrm{~s}, 1 \mathrm{H}), 2.31(\mathrm{~m}$, $2 \mathrm{H}), 2.06(\mathrm{~m}, 4 \mathrm{H}), 1.89\left(\mathrm{td}, 4 \mathrm{H}, J_{\mathrm{a}}=J_{\mathrm{b}}=6.9 \mathrm{~Hz}\right), 1.49(\mathrm{q}, 2 \mathrm{H}$, $J=6.9 \mathrm{~Hz}) ;{ }^{13} \mathrm{C} \mathrm{NMR}\left(\mathrm{CDCl}_{3}\right) \delta 138,132,128,128,122,115$, $89,85,81,79,62,37,33,28,18,15$. HRMS: calcd for $\mathrm{C}_{18} \mathrm{H}_{20} \mathrm{O}$ $\left(\mathrm{M}^{+}\right)$, m/e 252.1514; found, $m / e$ 252.1509. 9: Yield $=74 \% ; R_{f}$ $=0.23\left(10 \%\right.$ EtOAc in hexanes). IR $\left(\mathrm{CCl}_{4}\right) 3600,2936,1547$, $1245 \mathrm{~cm}^{-1} ;{ }^{1} \mathrm{H} \mathrm{NMR}\left(\mathrm{CDCl}_{3}\right) \delta 5.77$ (ddt, $1 \mathrm{H}, J_{\text {trans }}=17.0 \mathrm{~Hz}$, $\left.J_{\text {cis }}=10.3 \mathrm{~Hz}, J_{1}=6.6 \mathrm{~Hz}\right), 5.01\left(\mathrm{dd}, 1 \mathrm{H}, J_{\text {trans }}=17.0 \mathrm{~Hz}, J_{\text {gem }}\right.$ $=1.6 \mathrm{~Hz}), 4.96\left(\mathrm{dd}, 1 \mathrm{H}, J_{c i s}=10.3 \mathrm{~Hz}, J_{\text {gem }}=1.6 \mathrm{~Hz}\right), 4.49$ $\left(\mathrm{dt}, 1 \mathrm{H}, J_{\mathrm{a}}=J_{\mathrm{b}}=6.0 \mathrm{~Hz}\right), 2.44-2.20(\mathrm{~m}, 2 \mathrm{H}), 2.18-2.04(\mathrm{~m}$, $4 \mathrm{H}), 1.98(\mathrm{~d}, J=7.3 \mathrm{~Hz}, 1 \mathrm{H}), 1.85\left(\mathrm{dt}, J_{\mathrm{a}}=J_{\mathrm{b}}=6.7 \mathrm{~Hz}, 2 \mathrm{H}\right)$, $1.55(\mathrm{~m}, 2 \mathrm{H}) ;{ }^{13} \mathrm{C} \mathrm{NMR}\left(\mathrm{CDCl}_{3}\right) \delta 138,115,106,90,81,79,62$, $37,33,28,18,15,0$. HRMS: calcd for $\mathrm{C}_{15} \mathrm{H}_{23} \mathrm{OSi}\left(\mathrm{M}^{+}-1\right)$, m/e 247.1518; found, $m / e$ 247.1516.

3-((Trimethylsilyl)oxy)-1-(trimethylsilyl)dodec-1,6-diyn12-ene (10). To 9 (500 $\mathrm{mg}, 2.02 \mathrm{mmol})$ dissolved in $10 \mathrm{~mL}$ of THF are added $16 \mathrm{mmol}$ of triethylamine and, after cooling to $0^{\circ} \mathrm{C}, 6.1 \mathrm{mmol}$ of trimethylsilyl chloride. The solution is stirred overnight and then worked up as usual to afford, after flash chromatography, the desired product: Yield $=82 \% ; R_{f}$ $=0.73(10 \%$ EtOAc in hexanes $) ; \mathrm{GC} \mathrm{Rt}=11.3 \mathrm{~min} ; \mathrm{IR}\left(\mathrm{CCl}_{4}\right)$ $3320,2965,2184,1259 \mathrm{~cm}^{-1} ;{ }^{1} \mathrm{H}$ NMR $\left(\mathrm{CDCl}_{3}\right) \delta 5.78$ (ddt, $\left.1 \mathrm{H}, J_{\text {trans }}=17.0 \mathrm{~Hz}, J_{\text {cis }}=10.3 \mathrm{~Hz}, J_{1}=6.6 \mathrm{~Hz}\right), 5.01(\mathrm{dd}, 1 \mathrm{H}$, $\left.J_{\text {trans }}=17.0 \mathrm{~Hz}, J_{\text {gem }}=1.6 \mathrm{~Hz}\right), 4.95\left(\mathrm{dd}, 1 \mathrm{H}, J_{\text {cis }}=10.3 \mathrm{~Hz}\right.$ $\left.J_{\text {gem }}=1.6 \mathrm{~Hz}\right), 2.23-2.20(\mathrm{~m}, 2 \mathrm{H}), 2.18-2.06(\mathrm{~m}, 4 \mathrm{H}), 1.88-$ $1.74(\mathrm{~m}, 2 \mathrm{H}), 1.54(\mathrm{q}, 2 \mathrm{H}, J=7.5 \mathrm{~Hz}) ;{ }^{13} \mathrm{C} \mathrm{NMR}\left(\mathrm{CDCl}_{3}\right) \delta$ 
$138,115,107,89,80,79,62,38,33,28,18,15,0.1,-0.2$. HRMS: calcd for $\mathrm{C}_{18} \mathrm{H}_{32} \mathrm{OSi}_{2}\left(\mathrm{M}^{+}\right)$, m/e 320.1992 ; found, m/e 320.1992 .

General Procedure for the Cyclocarbonylation Reactions. To $2 \mathrm{mmol}$ of the enediyne in $10 \mathrm{~mL}$ of toluene in a Fisher-Porter vessel is added $10 \mathrm{mmol}$ of pentacarbonyliron filtered through a short pad of Celite. The reaction vessel is sealed and degassed by three freeze-pump-thaw cycles. During the last cycle it is charged with 100 psi of CO (50 psi for the hydroxy- and trimethylsilyloxy-substituted endiynes), and then it is heated at $125-130^{\circ} \mathrm{C}$ for 22 hours. After cooling and release of the pressure, the reaction mixture is diluted with $10 \mathrm{~mL}$ of methylene chloride and filtered through a 30 $\mathrm{mm}$ Celite column to remove iron impurities; the solvent is evaporated and the dark residue chromatographed through a short column of silica gel to afford, after removal of the solvent, pure complex.

Tricarbonyl 2-(pent-4-enyl)-4-phenylbicyclo[3.3.0]octa1,4-dien-3-one \}iron (11). This was obtained from 4: Yield $78 \% ; R_{f}=0.35\left(\right.$ EtOAc); IR $\left(\mathrm{CDCl}_{3}\right) 2063,2011,1979 \mathrm{~cm}^{-1} ;{ }^{1} \mathrm{H}$ NMR $\left(\mathrm{CDCl}_{3}\right) \delta 7.94-7.90(\mathrm{~m}, 2 \mathrm{H}), 7.35-7.20(\mathrm{~m}, 3 \mathrm{H}), 5.82$ (ddt, $1 \mathrm{H}, J_{\text {trans }}=17.0 \mathrm{~Hz}, J_{\text {cis }}=10.3 \mathrm{~Hz}, J_{1}=6.6 \mathrm{~Hz}$ ), 5.01 $\left(\mathrm{dd}, 1 \mathrm{H}, J_{\text {trans }}=17.0 \mathrm{~Hz}, J_{\text {gem }}=1.6 \mathrm{~Hz}\right), 4.95\left(\mathrm{dd}, 1 \mathrm{H}, J_{\text {cis }}=\right.$ $\left.10.3 \mathrm{~Hz}, J_{g e m}=1.6 \mathrm{~Hz}\right), 2.99-2.86(\mathrm{~m}, 2 \mathrm{H}), 2.64-2.57(\mathrm{~m}, 2 \mathrm{H})$, $2.57-2.37(\mathrm{~m}, 2 \mathrm{H}), 2.18-1.98(\mathrm{~m}, 4 \mathrm{H}), 1.75-1.58(\mathrm{~m}, 2 \mathrm{H}) ;{ }^{13} \mathrm{C}$ $\operatorname{NMR}\left(\mathrm{CDCl}_{3}\right) \delta 208.9,172.0,138.0,132.4,128.6,127.9,127.6$, $115.0,108.5,103.8,82.2,77.9,33.8,28.9,28.4,26.1,25.8,24.4$. HRMS: calcd for $\mathrm{C}_{19} \mathrm{H}_{24} \mathrm{O}_{4} \mathrm{SiFe}\left(\mathrm{M}^{+}\right), 0404.0711$. Found: 404.0716 .

Tricarbonyl $\{2$-(pent-4-enyl)-4-(trimethylsilyl)bicyclo[3.3.0] octa-1,4-dien-3-one\}iron (12). This was obtained from 5: Yield 58\%; $R_{f}=0.08$ (10\% EtOAc in hexanes); IR $\left(\mathrm{CDCl}_{3}\right) 2067,2006,2000 \mathrm{~cm}^{-1} ;{ }^{1} \mathrm{H}$ NMR $\left(\mathrm{CDCl}_{3}\right) \delta 5.79$ (ddt, $\left.1 \mathrm{H}, J_{\text {trans }}=17.0 \mathrm{~Hz}, J_{\text {cis }}=10.3 \mathrm{~Hz}, J_{1}=6.6 \mathrm{~Hz}\right), 5.01(\mathrm{dd}, 1 \mathrm{H}$, $\left.J_{\text {trans }}=17.0 \mathrm{~Hz}, J_{\text {gem }}=1.6 \mathrm{~Hz}\right), 4.95\left(\mathrm{dd}, 1 \mathrm{H}, J_{c i s}=10.3 \mathrm{~Hz}\right.$, $\left.J_{g e m}=1.6 \mathrm{~Hz}\right), 2.57-2.48(\mathrm{~m}, 4 \mathrm{H}), 2.46-2.22(\mathrm{~m}, 2 \mathrm{H}), 2.11$ $\left(\mathrm{dt}, 2 \mathrm{H}, J_{1}=J_{2}=7.2 \mathrm{~Hz}\right), 2.03-1.80(\mathrm{~m}, 2 \mathrm{H}), 1.79-1.53(\mathrm{~m}$, $2 \mathrm{H}), 0.25(\mathrm{~s}, 9 \mathrm{H}) ;{ }^{13} \mathrm{C} \mathrm{NMR}\left(\mathrm{CDCl}_{3}\right) \delta 209.0,178.7,138.1,115.0$, $112.3,112.2,85.1,67.2,33.9,28.9,27.4,25.9,25.8,24.4,-0.7$. HRMS: calcd for $\mathrm{C}_{19} \mathrm{H}_{24} \mathrm{O}_{4} \mathrm{SiFe}\left(\mathrm{M}^{+}\right)$, m/e 400.0793 ; found, m/e 400.0832 .

Tricarbonyl\{2-(pent-4-enyl)bicyclo[3.3.0]octa-1,4-dien3-one \}iron (13). This was obtained from 6: Yield $=90 \% ; R_{f}$ $=0.21\left(30 \%\right.$ EtOAc in hexanes); IR $\left(\mathrm{CCl}_{4}\right) 2071,2014,1991$, $1653 \mathrm{~cm}^{-1} ;{ }^{1} \mathrm{H} \mathrm{NMR}\left(\mathrm{CDCl}_{3}\right) \delta 5.77$ (ddt, $1 \mathrm{H}, J_{\text {trans }}=17.0 \mathrm{~Hz}$, $\left.J_{c i s}=10.3 \mathrm{~Hz}, J_{1}=6.6 \mathrm{~Hz}\right), 5.00\left(\mathrm{dd}, 1 \mathrm{H}, J_{\text {trans }}=17.0 \mathrm{~Hz}, J_{\text {gem }}\right.$ $=1.6 \mathrm{~Hz}), 4.93\left(\mathrm{dd}, 1 \mathrm{H}, J_{\text {cis }}=10.3 \mathrm{~Hz}, J_{\text {gem }}=1.6 \mathrm{~Hz}\right), 4.02(\mathrm{~s}$, $1 \mathrm{H}), 2.66-2.48(\mathrm{~m}, 4 \mathrm{H}), 2.44-2.29(\mathrm{~m}, 2 \mathrm{H}), 2.22-1.85(\mathrm{~m}, 4 \mathrm{H})$, $1.67-1.51(\mathrm{~m}, 2 \mathrm{H}) ;{ }^{13} \mathrm{C}$ NMR $\left(\mathrm{CDCl}_{3}\right) \delta 208.4,174.1,137.8$, $115.0,110.7,105.7,82.2,84.7,59.8,33.7,28.8,26.7,26.1,26.0$, 24.3. HRMS: calcd for $\mathrm{C}_{16} \mathrm{H}_{16} \mathrm{O}_{4} \mathrm{Fe}\left(\mathrm{M}^{+}\right)$, m/e 328.0398; found, m/e 328.0390.

Tricarbonyl 2-(pent-4-enyl)-4-phenyl-6-hydroxybicyclo[3.3.0] octa-1,4-dien-3-one] iron (14). This was obtained from 8: Yield $=75 \%$ (mixture of diastereomers); $R_{f}=0.12-$ 0.25 (30\% EtOAc in hexanes); IR $\left(\mathrm{CCl}_{4}\right) 2071,2026,2000 \mathrm{~cm}^{-1}$; ${ }^{1} \mathrm{H}$ NMR $\left(\mathrm{CDCl}_{3}\right) \delta 8.14\left(\mathrm{dd}, 2 \mathrm{H}, J_{1}=8.2 \mathrm{~Hz}, J_{2}=1.5 \mathrm{~Hz}\right)$, $7.36-7.25(\mathrm{~m}, 3 \mathrm{H}), 5.70$ (ddt, $1 \mathrm{H}, J_{\text {trans }}=17.0 \mathrm{~Hz}, J_{\text {cis }}=10.3$ $\left.\mathrm{Hz}, J_{1}=6.6 \mathrm{~Hz}\right), 5.38(\mathrm{t}, 1 \mathrm{H}), 5.02\left(\mathrm{dd}, 1 \mathrm{H}, J_{\text {trans }}=17.0 \mathrm{~Hz}\right.$, $\left.J_{g e m}=1.6 \mathrm{~Hz}\right), 4.96\left(\mathrm{dd}, 1 \mathrm{H}, J_{c i s}=10.3 \mathrm{~Hz}, J_{g e m}=1.6 \mathrm{~Hz}\right)$, $4.06(\mathrm{~d}, 1 \mathrm{H}), 3.04-2.90(\mathrm{~m}, 1 \mathrm{H}), 2.51-2.2 .25(\mathrm{~m}, 3 \mathrm{H}), 2.12-$ $1.93(\mathrm{~m}, 3 \mathrm{H}), 1.91-1.56(\mathrm{~m}, 2 \mathrm{H}), 1.40-1.23(\mathrm{~m}, 1 \mathrm{H}) ;{ }^{13} \mathrm{C}$ NMR $\left(\mathrm{CDCl}_{3}\right) \delta$ (1st diastereomer) 208.2, 171.0, 137.9, 131.4, 129.1, $128.3,127.8,115.1,110.1,104.8,81.9,77.7,71.2,35.7,33.7$, $28.9,24.1,23.0, \delta$ (2nd diastereomer) 208.0, 172.4, 137.9, 131.8, $128.7,128.2,127.6,114.9,111.3,98.9,85.1,75.2,72.3,36.8$, 33.8, 29.3, 23.7, 23.6. HRMS: calcd for $\mathrm{C}_{22} \mathrm{H}_{20} \mathrm{O}_{5} \mathrm{Fe}\left(\mathrm{M}^{+}\right)$, m/e 420.0660 ; found, $m / e 420.0641$.

Tricarbonyl \{ 2-(pent-4-enyl)-4-(trimethylsilyl)-6-hydroxybicyclo[3.3.0]octa-1,4-dien-3-one\}iron (15). This was obtained from 9: Yield $=65 \%$ (mixture of diastereomers); $R_{f}$ $=0.09$ (10\% EtOAc in hexanes); IR $\left(\mathrm{CCl}_{4}\right) 2069,2016,1989$ $\mathrm{cm}^{-1} ;{ }^{1} \mathrm{H} \mathrm{NMR}\left(\mathrm{CDCl}_{3}\right) \delta 5.78\left(\mathrm{ddt}, 1 \mathrm{H}, J_{\text {trans }}=17.0 \mathrm{~Hz}, J_{\text {cis }}=\right.$ $\left.10.3 \mathrm{~Hz}, J_{1}=6.6 \mathrm{~Hz}\right), 5.13(\mathrm{t}, 1 \mathrm{H}, J=9.7 \mathrm{~Hz}), 4.99(\mathrm{dd}, 1 \mathrm{H}$, $\left.J_{\text {trans }}=17.0 \mathrm{~Hz}, J_{\text {gem }}=1.6 \mathrm{~Hz}\right), 4.94\left(\mathrm{dd}, 1 \mathrm{H}, J_{\text {cis }}=10.3 \mathrm{~Hz}\right.$, $\left.J_{\text {gem }}=1.6 \mathrm{~Hz}\right), 3.11(\mathrm{~s}, 1 \mathrm{H}), 3.00-1.51(\mathrm{~m}, 10 \mathrm{H}), 0.23(\mathrm{~s}, 9 \mathrm{H})$; ${ }^{13} \mathrm{C} \mathrm{NMR}\left(\mathrm{CDCl}_{3}\right) \delta 209,(179,178), 138,115,(114,112),(113$, $109),(87,85),(72,71),(66,65),(36,35), 34,29,(24,23), 24$, $(-0.1,-0.8)$. HRMS: caled for $\mathrm{C}_{19} \mathrm{H}_{24} \mathrm{O}_{5} \mathrm{SiFe}\left(\mathrm{M}^{+}\right)$, m/e 416.0742; found, m/e 416.0590.

Tricarbonyl \{2-(pent-4-enyl)-4-(trimethylsilyl)-6-oxobicyclo[3.3.0]octa-1,4-dien-3-one\}iron (16). To $132 \mathrm{mg}$ $(0.32 \mathrm{mmol})$ of 15 in $5 \mathrm{~mL}$ of $\mathrm{CH}_{2} \mathrm{Cl}_{2}$ is added $103 \mathrm{mg}(0.48$ $\mathrm{mmol}$ ) of $\mathrm{PCC}$, and the reaction is stirred at room temperature overnight. Aqueous workup, drying over $\mathrm{MgSO}_{4}$ and removal of the solvent afford the desired ketone: Yield $=90 \% ; R_{f}=$ 0.40 (20\% EtOAc in hexanes); IR $\left(\mathrm{CCl}_{4}\right) 2081,2027,2001,1723$, $1653 \mathrm{~cm}^{-1} ;{ }^{1} \mathrm{H}$ NMR $\left(\mathrm{CDCl}_{3}\right) \delta 5.77$ (ddt, $1 \mathrm{H}, J_{\text {trans }}=17.0 \mathrm{~Hz}$, $\left.J_{\text {cis }}=10.3 \mathrm{~Hz}, J_{1}=6.6 \mathrm{~Hz}\right), 5.01\left(\mathrm{dd}, 1 \mathrm{H}, J_{\text {trans }}=17.0 \mathrm{~Hz}, J_{\mathrm{gem}}\right.$ $=1.6 \mathrm{~Hz}), 4.96\left(\mathrm{dd}, 1 \mathrm{H}, J_{c i s}=10.3 \mathrm{~Hz}, \mathrm{~J}_{s y n}=1.6 \mathrm{~Hz}\right), 3.14-$ $2.91(\mathrm{~m}, 2 \mathrm{H}), 2.75(\mathrm{t}, 2 \mathrm{H}, J=5.3 \mathrm{~Hz}), 2.35-2.01(\mathrm{~m}, 4 \mathrm{H}), 1.76-$ $1.52(\mathrm{~m}, 2 \mathrm{H}) ;{ }^{13} \mathrm{C} \mathrm{NMR}\left(\mathrm{CDCl}_{3}\right) \delta 207,179,137,123,115,93$, $92,65,64,37,34,29,24,22,-0.6$. HRMS: calcd for $\mathrm{C}_{19} \mathrm{H}_{22} \mathrm{O}_{5}$ $\mathrm{SiFe}(\mathrm{M}), \mathrm{m} / \mathrm{e}$ 414.0586; found, $m / e 414.0586$

Tricarbonyl \{2-(pent-4-enyl)-4-(trimethylsilyl)-6-((trimethylsilyl)oxy)bicyclo[3.3.0]octa-1,4-dien-3-one\}iron (17). This was obtained from 10: Yield $=81 \%$ (mixture of diastereomers); $R_{f}=0.46-0.56$ (20\% EtOAc in hexanes); IR $\left(\mathrm{CCl}_{4}\right)$ 2963, 2070, 2014, 1990, 1641, $1257 \mathrm{~cm}^{-1} ;{ }^{1} \mathrm{H} \mathrm{NMR}\left(\mathrm{CDCl}_{3}\right) \delta$ 5.77 (ddt, $1 \mathrm{H}, J_{\text {trans }}=17.0 \mathrm{~Hz}, J_{\text {cis }}=10.3 \mathrm{~Hz}, J_{1}=6.6 \mathrm{~Hz}$ ), $5.09(\mathrm{t}, 1 \mathrm{H}, J=7.5 \mathrm{~Hz}), 4.98\left(\mathrm{dd}, 1 \mathrm{H}, J_{\text {trans }}=17.0 \mathrm{~Hz}, J_{\text {gem }}=\right.$ $1.6 \mathrm{~Hz}), 4.93\left(\mathrm{dd}, 1 \mathrm{H}, J_{\text {cis }}=10.3 \mathrm{~Hz}, J_{\text {gem }}=1.6 \mathrm{~Hz}\right), 2.92-1.50$ $(\mathrm{m}, 10 \mathrm{H}), 0.25(2 \mathrm{~s}, 9 \mathrm{H}), 0.15(2 \mathrm{~s}, 9 \mathrm{H}) ;{ }^{13} \mathrm{C} \mathrm{NMR}\left(\mathrm{CDCl}_{3}\right) \delta 209$ (2), (179, 178), 138, 115, (115, 112), (114, 109), (87, 84), (73, $72),(66,65), 36(2), 34,29(2) ;(24,23), 24,(0.7,0.2),(0.1,-0.9)$. HRMS: calcd for $\mathrm{C}_{22} \mathrm{H}_{32} \mathrm{O}_{5} \mathrm{Si}_{2} \mathrm{Fe}\left(\mathrm{M}^{+}\right)$, m/e 488.1138 ; found, m/e 488.1151.

Tricarbonyl $\{2-($ pent-4-enyl)-4-phenyl-6-((methoxymethylene)oxy)bicyclo[3.3.0]octa-1,4-dien-3-one]iron (18). The corresponding alcohol $14(145 \mathrm{mg}, 0.35 \mathrm{mmol})$ is dissolved in $\mathrm{CH}_{2} \mathrm{Cl}_{2}$ with $2.8 \mathrm{mmol}$ of Hünigs base, $1.7 \mathrm{mmol}$ of methoxymethyl chloride is added at $0{ }^{\circ} \mathrm{C}$, and the reaction is warmed to $55^{\circ} \mathrm{C}$ for $48 \mathrm{~h}$. Aqueous workup, followed by drying over $\mathrm{MgSO}_{4}$ and flash chromatography, affords the desired methoxymethyl ether as a 2:1 mixture of diastereomers: Yield $=100 \%$ (mixture of diastereomers); $R_{f}=0.30-$ 0.40 (30\% EtOAc in hexanes); IR $\left(\mathrm{CCl}_{4}\right) 2945,2069,2018,1990$, $1645 \mathrm{~cm}^{-1} ;{ }^{1} \mathrm{H}$ NMR (1st diastereomer, $\left.R_{f}=0.4\right)\left(\mathrm{CDCl}_{3}\right) \delta 8.05$ $(\mathrm{d}, 2 \mathrm{H}, J=7.3 \mathrm{~Hz}), 7.32(\mathrm{~m}, 3 \mathrm{H}), 5.82\left(\mathrm{ddt}, 1 \mathrm{H}, J_{\text {trans }}=17.0\right.$ $\left.\mathrm{Hz}, J_{\text {cis }}=10.3 \mathrm{~Hz}, J_{1}=6.6 \mathrm{~Hz}\right), 5.37(\mathrm{~d}, 1 \mathrm{H}, J=4.7 \mathrm{~Hz}), 5.03$ (dd, $\left.1 \mathrm{H}, J_{\text {trans }}=17.0 \mathrm{~Hz}, J_{\text {gem }}=1.6 \mathrm{~Hz}\right), 4.98\left(\mathrm{dd}, 1 \mathrm{H}, J_{\text {cis }}=\right.$ $\left.10.3 \mathrm{~Hz}, J_{\text {gem }}=1.6 \mathrm{~Hz}\right), 4.74\left(\mathrm{~d}, 1 \mathrm{H}, J_{g e m}=7.0 \mathrm{~Hz}\right), 4.64(\mathrm{~d}$, $\left.1 \mathrm{H}, J_{g e m}=7.0 \mathrm{~Hz}\right), 3.31(\mathrm{~s}, 3 \mathrm{H}), 3.00-1.60(\mathrm{~m}, 10 \mathrm{H}),(2 \mathrm{nd}$ diastereomer, $\left.R_{f}=0.3\right)\left(\mathrm{CDCl}_{3}\right) \delta 7.90(\mathrm{~d}, 2 \mathrm{H}, J=7.3 \mathrm{~Hz})$, $7.26(\mathrm{~m}, 3 \mathrm{H}), 5.79\left(\mathrm{ddt}, 1 \mathrm{H}, J_{\text {trans }}=17.0 \mathrm{~Hz}, J_{\text {cis }}=10.3 \mathrm{~Hz}, J_{1}\right.$ $=6.6 \mathrm{~Hz}), 5.21(\mathrm{t}, 1 \mathrm{H}, J=7.4 \mathrm{~Hz}), 5.03\left(\mathrm{dd}, 1 \mathrm{H}, J_{\text {trans }}=17.0\right.$ $\left.\mathrm{Hz}, J_{\mathrm{gem}}=1.6 \mathrm{~Hz}\right), 4.96\left(\mathrm{dd}, 1 \mathrm{H}, J_{c i s}=10.3 \mathrm{~Hz}, J_{g e m}=1.6\right.$ $\mathrm{Hz}), 4.74(\mathrm{~s}, 2 \mathrm{H})), 3.37(\mathrm{~s}, 3 \mathrm{H}), 2.85-1.55(\mathrm{~m}, 10 \mathrm{H}) ;{ }^{13} \mathrm{C}$ NMR (1st diastereomer, $\left.R_{f}=0.4\right)\left(\mathrm{CDCl}_{3}\right) \delta 208,173,138,132,129$, $128,128,115,110,99,95,84,77,56,34,33,29,24,24$, (2nd diastereomer, $\left.R_{f}=0.3\right)\left(\mathrm{CDCl}_{3}\right) \delta 208,171,138,131,129,128$, $127,115,109,101,96,82,78,76,56,34,33,29,24,23$. HRMS: calcd for $\mathrm{C}_{21} \mathrm{H}_{28} \mathrm{O}_{6} \mathrm{SiFe}\left(\mathrm{M}^{+}\right)$, m/e 464.0922; found, m/e 464.0922 .

Tricarbonyl $\{2-($ pent-4-enyl $)-4-($ trimethylsilyl)-6-. ((methoxymethylene)oxy)bicyclo[3.3.0]octa-1,4-dien-3one iron (19). The corresponding alcohol $15(80 \mathrm{mg}, 0.19$ $\mathrm{mmol}$ ) is dissolved in $\mathrm{CH}_{2} \mathrm{Cl}_{2}$ with $1.52 \mathrm{mmol}$ of Hünigs base, $0.80 \mathrm{mmol}$ of methoxymethyl chloride are added at $0{ }^{\circ} \mathrm{C}$, and the reaction is warmed to $55^{\circ} \mathrm{C}$ for $48 \mathrm{~h}$. Aqueous workup, followed by drying over $\mathrm{MgSO}_{4}$ and flash chromatography, affords the desired methoxymethyl ether as a mixture of diastereomers: Yield $=100 \%$ (mixture of diastereomers); $R_{f}$ $=0.68$ (20\% EtOAc in hexanes); IR $\left(\mathrm{CCl}_{4}\right) 2956,2066,2013$, 
$1990,1641 \mathrm{~cm}^{-1} ;{ }^{1} \mathrm{H}$ NMR $\left(\mathrm{CDCl}_{3}\right) \delta 5.76\left(\mathrm{ddt}, 1 \mathrm{H}, J_{\text {trans }}=\right.$ $\left.17.0 \mathrm{~Hz}, J_{\text {cis }}=10.3 \mathrm{~Hz}, J_{1}=6.6 \mathrm{~Hz}\right), 4.98\left(\mathrm{dd}, 1 \mathrm{H}, J_{\text {trans }}=\right.$ $\left.17.0 \mathrm{~Hz}, J_{\mathrm{gem}}=1.6 \mathrm{~Hz}\right), 4.94\left(\mathrm{dd}, 1 \mathrm{H}, J_{c i s}=10.3 \mathrm{~Hz}, J_{\mathrm{gem}}=\right.$ $1.6 \mathrm{~Hz}), 4.84(2 \mathrm{t}, 1 \mathrm{H}, J=6.7 \mathrm{~Hz}), 4.74\left(\mathrm{~d}, 1 \mathrm{H}, J_{\mathrm{gem}}=7.0 \mathrm{~Hz}\right)$, $4.68\left(\mathrm{~d}, 1 \mathrm{H}, J_{g e m}=7.0 \mathrm{~Hz}\right), 3.38(\mathrm{~s}, 3 \mathrm{H}), 2.92-1.50(\mathrm{~m}, 10 \mathrm{H})$, $0.25(\mathrm{~s}, 9 \mathrm{H}) ;{ }^{13} \mathrm{C} \mathrm{NMR}\left(\mathrm{CDCl}_{3}\right) \delta 208,(179,178), 138,127,125$, $120,115,114,113,107,98,95,87,78,77,76,57,56,33,28$, $24,24,23,-0.1,-1$. HRMS: calcd for $\mathrm{C}_{21} \mathrm{H}_{28} \mathrm{O}_{6} \mathrm{SiFe}\left(\mathrm{M}^{+}\right)$, m/e 460.1004; found, $m / e 460.1003$.

Decomplexation Reactions. The general procedure consists in dissolving the desired complex $(0.2 \mathrm{mmol})$ in $5 \mathrm{~mL}$ of $N, N$-dimethylacetamide and cooling to $-10^{\circ} \mathrm{C}$ under air, followed by addition of $0.8 \mathrm{mmol}$ of trimethylamine $N$-oxide. The mixture is then stirred for $1 \mathrm{~h}$ after which time the temperature is raised to $-5{ }^{\circ} \mathrm{C}$ followed by additional $11 \mathrm{~h}$ of stirring. With care taken to maintain the product at around $0{ }^{\circ} \mathrm{C}, 10 \mathrm{~mL}$ of ethyl ether is added, and the solution is filtered through a short column of Celite, diluted with additional 10 $\mathrm{mL}$ of ether, and washed at least 6 times with $15 \mathrm{~mL}$ aliquots of cold half-saturated brine. The organic layer is dried over $\mathrm{MgSO}_{4}$ in an ice bath and the solvent removed by rotary evaporation without heating. In all cases the crude ${ }^{1} \mathrm{H}$ NMR spectrum shows very few peaks due to impurities; the GC trace on the other hand shows a purity, relative to the crude mixture, of around $70 \%$. After purification by HPLC the yield is somewhat lower due to losses in the chromatographic process. The three different yields are reported in each case.

2-(Pent-4-enyl)-4-phenylbicyclo[3.3.0]octa-1,5-dien-3one (20). This was obtained from 11: Yield, crude $65 \%$, GC $38 \%$, HPLC $10 \% ; R_{f}=0.28$ (30\% EtOAc in hexanes); GC Rt $=$ $18.6 \mathrm{~min}$; IR $\left(\mathrm{CCl}_{4}\right) 3558,2939,1716,1634 \mathrm{~cm}^{-1} ;{ }^{1} \mathrm{H}$ NMR $(400$ $\left.\mathrm{MHz}, \mathrm{CDCl}_{3}\right) \delta 7.38-7.24(\mathrm{~m}, 5 \mathrm{H}), 6.16(\mathrm{t}, 1 \mathrm{H}, J=2.6 \mathrm{~Hz})$, 5.79 (ddt, $1 \mathrm{H}, J_{\text {trans }}=17.0 \mathrm{~Hz}, J_{\text {cis }}=10.3 \mathrm{~Hz}, J_{1}=6.6 \mathrm{~Hz}$ ), $4.99\left(\mathrm{dd}, 1 \mathrm{H}, J_{\text {trans }}=17.0 \mathrm{~Hz}, J_{\text {gem }}=1.6 \mathrm{~Hz}\right), 4.94\left(\mathrm{dd}, 1 \mathrm{H}, J_{\text {cis }}\right.$ $\left.=10.3 \mathrm{~Hz}, J_{g e m}=1.6 \mathrm{~Hz}\right), 2.93(\mathrm{~s}, 2 \mathrm{H}), 2.90(\mathrm{~m}, 2 \mathrm{H}), 2.84(\mathrm{~m}$, $2 \mathrm{H}), 2.33(\mathrm{~m}, 2 \mathrm{H}), 2.06(\mathrm{~m}, 2 \mathrm{H}), 1.62(\mathrm{~m}, 2 \mathrm{H}) ;{ }^{13} \mathrm{C} \mathrm{NMR}\left(\mathrm{CDCl}_{3}\right)$ $\delta 208,182,151,140,138,130,130,128,127,125,115,76,36$, 34, 27, 26, 24. HRMS: calcd for $\mathrm{C}_{19} \mathrm{H}_{20} \mathrm{O}\left(\mathrm{M}^{+}\right)$, m/e 264.1514; found, $m / e$ 264.1512.

2-(Pent-4-enyl)bicyclo[3.3.0]octa-1,5-dien-3-one (21). This was obtained from 12: Yield, crude $61 \%$, GC 45\%, HPLC $12 \% ; R_{f}=0.32\left(20 \%\right.$ EtOAc in hexanes); IR $\left(\mathrm{CCl}_{4}\right) 2951,1717$, $1634 \mathrm{~cm}^{-1} ;{ }^{1} \mathrm{H}$ NMR $\left(400 \mathrm{MHz}, \mathrm{CDCl}_{3}\right) \delta 5.96(\mathrm{t}, 1 \mathrm{H}, J=2.5$
$\mathrm{Hz}), 5.79\left(\mathrm{ddt}, 1 \mathrm{H}, J_{\text {trans }}=17.0 \mathrm{~Hz}, J_{\text {cis }}=10.3 \mathrm{~Hz}, J_{1}=6.6\right.$ $\mathrm{Hz}), 4.99\left(\mathrm{dd}, 1 \mathrm{H}, J_{\text {trans }}=17.0 \mathrm{~Hz}, J_{\mathrm{gem}}=1.6 \mathrm{~Hz}\right), 4.93(\mathrm{dd}$, $\left.1 \mathrm{H}, J_{\text {cis }}=10.3 \mathrm{~Hz}, J_{g e m}=1.6 \mathrm{~Hz}\right), 2.85(\mathrm{~s}, 2 \mathrm{H}), 2.83(\mathrm{~m}, 2 \mathrm{H})$, $2.72(\mathrm{~m}, 2 \mathrm{H}), 2.25(\mathrm{t}, 2 \mathrm{H}, J=7.7 \mathrm{~Hz}), 2.03(\mathrm{q}, 2 \mathrm{H}, J=7.7$ $\mathrm{Hz}), 1.62(\mathrm{p}, 2 \mathrm{H}, J=7.7 \mathrm{~Hz}) ;{ }^{13} \mathrm{C} \mathrm{NMR}\left(\mathrm{CD}_{3} \mathrm{Cl}\right) \delta 208,182$, $144,138,134,129,115,36,36,34,27,25,23$. HRMS: calcd for $\mathrm{C}_{13} \mathrm{H}_{16} \mathrm{O}\left(\mathrm{M}^{+}\right)$, m/e 188.1201; found, $m / e$ 188.1202.

2-(Pent-4-enyl)-4-phenyl-6-((methoxymethylene)oxy)bicyclo[3.3.0]octa-1,5-dien-3-one (22). This was obtained from 18: Yield, crude 58\%, GC 37\%, HPLC 8\%; $R_{f}=0.40(20 \%$ EtOAc in hexanes); IR $\left(\mathrm{CCl}_{4}\right) 2986,2940,2866,1697 \mathrm{~cm}^{-1} ;{ }^{1} \mathrm{H}$ NMR $\left(\mathrm{CDCl}_{3}\right) \delta 7.28-7.05(\mathrm{~m}, 5 \mathrm{H}), 5.73\left(\mathrm{ddt}, 1 \mathrm{H}, J_{\text {trans }}=17.0\right.$ $\left.\mathrm{Hz}, J_{c i s}=10.3 \mathrm{~Hz}, J_{1}=6.6 \mathrm{~Hz}\right), 4.92\left(\mathrm{dd}, 1 \mathrm{H}, J_{\text {trans }}=17.0 \mathrm{~Hz}\right.$, $J_{\text {gem }}=1.6 \mathrm{~Hz}$ ), $4.86\left(\mathrm{dd}, 1 \mathrm{H}, J_{\text {cis }}=10.3 \mathrm{~Hz}, J_{\mathrm{gem}}=1.6 \mathrm{~Hz}\right.$ ), $4.82(\mathrm{~d}, 1 \mathrm{H}, J=6.2 \mathrm{~Hz}), 4.54(\mathrm{~d}, 1 \mathrm{H}, J=6.2 \mathrm{~Hz}), 3.96(\mathrm{~s}, 1 \mathrm{H})$, $3.24(\mathrm{~s}, 3 \mathrm{H}), 2.98-2.80(\mathrm{~m}, 4 \mathrm{H}), 2.16\left(\mathrm{td}, 2 \mathrm{H}, J_{1}=2.9 \mathrm{~Hz}, J_{2}\right.$ $=7.5 \mathrm{~Hz}), 1.96\left(\mathrm{dt}, 2 \mathrm{H}, J_{1}=6.6 \mathrm{~Hz}, J_{2}=7.5 \mathrm{~Hz}\right), 1.50(\mathrm{p}, 2 \mathrm{H}$, $J=7.5 \mathrm{~Hz}) ;{ }^{13} \mathrm{C} \mathrm{NMR}\left(\mathrm{CDCl}_{3}\right) \delta 206,183,157,139,129,128$, $127,127,120,115,95,57,53,34,34,27,23,23$. HRMS: calcd for $\mathrm{C}_{21} \mathrm{H}_{24} \mathrm{O}_{3}\left(\mathrm{M}^{+}\right)$, m/e 324.1725; found, m/e 324.1721.

2-(Pent-4-enyl)-6-((methoxymethylene)oxy)bicyclo[3.3.0]octa-1,5-dien-3-one (23). This was obtained from 19: Yield, crude $75 \%$, GC $49 \%$, HPLC $15 \% ; R_{f}=0.30(30 \%$ EtOAc in hexanes); IR $\left(\mathrm{CCl}_{4}\right) 2933,1694,1669,1620 \mathrm{~cm}^{-1} ;{ }^{1} \mathrm{H}$ NMR $\left(\mathrm{CDCl}_{3}\right) \delta 5.79$ (ddt, $1 \mathrm{H}, J_{\text {trans }}=17.0 \mathrm{~Hz}, J_{\text {cis }}=10.3 \mathrm{~Hz}, J_{1}=$ $6.6 \mathrm{~Hz}), 5.05(\mathrm{~s}, 2 \mathrm{H}), 4.98\left(\mathrm{dd}, 1 \mathrm{H}, J_{\text {trans }}=17.0 \mathrm{~Hz}, J_{\text {gem }}=1.6\right.$ $\mathrm{Hz}), 4.92$ (dd, $\left.1 \mathrm{H}, J_{\text {cis }}=10.3 \mathrm{~Hz}, J_{\text {gem }}=1.6 \mathrm{~Hz}\right), 3.43(\mathrm{~s}, 3 \mathrm{H})$, $2.98(\mathrm{~s}, 2 \mathrm{H}), 2.84(\mathrm{~m}, 2 \mathrm{H}), 2.75(\mathrm{~m}, 2 \mathrm{H}), 2.19(\mathrm{t}, 2 \mathrm{H}, J=7.6$ $\mathrm{Hz}), 2.03(\mathrm{q}, 2 \mathrm{H}, J=7.6 \mathrm{~Hz}), 1.54(\mathrm{p}, 2 \mathrm{H}, J=7.6 \mathrm{~Hz}) ;{ }^{13} \mathrm{C}$ NMR $\left(\mathrm{CDCl}_{3}\right) \delta 207,183,156,139,129,115,114,95,57,37$, $35,34,27,23,23$. HRMS: calcd for $\mathrm{C}_{15} \mathrm{H}_{20} \mathrm{O}_{3}\left(\mathrm{M}^{+}\right), \mathrm{m} / \mathrm{e}$ 248.1412 found, $m / e$ 248.1413.

Acknowledgment. We are grateful to the National Science Foundation (Grant CHE 93-08105 to A.J.P.), the CNR (Italy; to A.P.) and the Fulbright Commission (to A.P.) for financial support of this research.

Supporting Information Available: Figures showing NMR spectra (49 pages). Ordering information is given on any current masthead page.

\section{OM950465B}

